\title{
PENGGUNAAN METODE ESTAFET LEARNING TERHADAP PENINGKATAN KEMAMPUAN BERPIKIR KRITIS DAN HASIL BELAJAR MAHASISWA PADA MATA KULIAH METODE NUMERIK
}

\author{
Heri Herwanto \\ Program Studi Teknik Informatika Universitas Kuningan, Jl Cut Nyak Dien No 36 A Cijoho, \\ Kuningan, Jawa Barat, Indonesia \\ heri.herwanto@uniku.ac.id
}

Abstract

The purpose of this study was to determine the effect of the application of estafet learning method to improve students' critical thinking skills, increase student learning outcomes, to determine the relationship of critical thinking to student learning outcomes and to determine the responses of students about the application of estafet learning method. This research is a quantitative research. The research instruments included test questions, observation sheets, and questionnaire sheets. The subjects in this study were students of the computer faculty of the fourth semester informatics engineering study program. Data analysis techniques used the gain test, correlation test and Likert scale analysis. The results showed an increase in critical thinking skills and learning outcomes in the medium category. The relationship between critical thinking skills and learning outcomes has a strong enough relationship in the very significant category. Student responses to the application of estafet learning method showed a positive response.

Keywords: Estafet learning method, critical thinking, learning outcomes

\begin{abstract}
Abstrak
Tujuan dari penelitian ini adalah untuk mengetahui pengaruh penerapan metode estafet learning terhadap peningkatan kemampuan berpikir kritis mahasiswa, peningkatan hasil belajar mahasiswa, untuk mengetahui hubungan berpikir kritis terhadap hasil belajar mahasiswa dan untuk mengetahui respon dari mahasiswa tentang penerapan metode pembelajaran estafet learning. Penelitian ini merupakan penelitian kuantitatif. Instrumen penelitian diantaranya soal tes, lembar observasi,dan lembar kuesioner. Subjek dalam penelitian ini adalah mahasiswa fakultas komputer program studi teknik informatikan semester 4. Teknik analisis data menggunakan uji gain, uji korelasi dan analisis skala likert. Hasil penelitian menunjukan adanya peningkatan kemampuan berpikir kritis dan hasil belajar dalam kategori sedang. Hubungan kemampuan berpikir kritis dan hasil belajar memiliki hubungan yang cukup kuat dalam kategori sangat signifikan. Respon mahasiswa terhadap penerapan metode pembelajaran estafet learning menunjukan respon yang positif.
\end{abstract}

Kata Kunci : metode estafet learning, berpikir kritis, hasil belajar

Cara Menulis Sitasi: Herwanto, H. (2016). Penggunaan metode estafet learning terhadap peningkatan kemampuan berpikir kritis dan hasil belajar mahasiswa pada mata kuliah metode numerik. Jurnal Edukasi dan Sains Matematika (JES-MAT),6 1), 11-22.

\section{PENDAHULUAN}

Proses pembelajaran pada lembaga pendidikan khususnya perguruan tinggi, harus melibatkan berbagai potensi yang dimiliki oleh mahasiswa dan dosen, baik melalui cara berpikir, sikap mental maupun 
sarana prasarana penunjang lainnya. Peserta didik dalam melakukan proses pembelajarannya harus ditempa dengan bimbingan dan latihan yang didesain untuk memiliki karakter, sikap dan cara berpikir yang kritis dalam menghadapi permasalahan.

Konsep berpikir kritis sangat diperlukan khususnya di fakultas komputer, hal ini dikarenakan matakuliah-matakuliah eksak merupakan pondasi dasar untuk memahami keilmuan komputer. Mata kuliah eksak akan mudah dipahami jika mahasiswa memiliki konsep berpikir kritis dan sikap pantang menyerah dalam pembelajaran untuk menyelesaikan pendidikan dengan tepat waktu. Menurut Pujiasih (2018), seseorang yang memiliki kemampuan matematika tinggi memiliki kemampuan berpikir kritis yang tinggi terlihat dalam pemecahan masalah yang lebih baik.

Fenomena yang terjadi terkadang matakuliah eksak merupakan suatu hal yang menakutkan, membosankan dan cepat menyerah dalam menghadapi pembelajaran. hal ini dikarenakan mahasiswa belum memiliki sikap mental dan cara berpikir kritis dalam pembelajaran, sehingga jika ini dibiarkan maka akan menghambat pemahaman dan menurunnya hasil belajar. Menurut (Chukwuyenum, 2013; Jacob, 2012; NCTM, 2000; Hendryawan, dkk., 2017) pengembangan kemampuan berpikir kritis dapat meningkatkan prestasi matematika.

Upaya yang harus dilakukan untuk mengatasi renadahnya kemampuan berpikir kritis dan hasil belajar yaitu dengan melakukan metode pembelajaran yang berpusat kepada mahasiswa sehingga seluruh potensi yang dimiliki mahasiswa dapat dieksplore dan dimaksimalkan melalui diskusi serta kolaborasi dengan teman-teman kelompoknya. Menurut Pujiasih (2018) Pada saat pembelajaran matematika peseta didik perlu diarahkan pada kegiatan-kegiatan yang mendorong untuk belajar secara aktif, baik secara mental, fisik maupun sosial merupakan salah satu upaya yang perlu dilakukan dengan berpikir kritis matematis. Hal tersebut penting, karena tujuan jangka panjang pembelajaran untuk mengembangkan diri dan mampu menyelesaikan permasalahan secara mandiri sebagai pemecah masalah yang baik.

Beberapa peneliti terdahulu telah melakukan penelitian tentang peningkatan kemampuan berpikir kritis dan hasil belajar menggunakan model pembelajaran yang memaksimalkan kemampuan mahasiswa diantaranya Putri, dkk (2018), melakukan penelitian yang mendeskripsikan kemampuan berpikir kritis siswa dalam pembelajaran matematika melalui teori APOS. Selanjutnya, Pujiasih (2018), melakukan penelitian mengkaji kemampuan berpikir kritis matematis siswa dalam pemecahan masalah soal SPLDV ditinjau dari kemampuan matematika.

Matakuliah metode numerik merupakan matakuliah eksak yang membutuhkan ketelitian dan ketekunan serta kemampuan berpikir kritis yang tinggi dalam meyelesaikan permasalahanpermasalahan yang diberikan melalui berbagai langkah itesasi (pendekatan) yang berkesinambungan. Metode pembelajaran yang sesuai dengan matakuliah metode numerik yaitu metode pembelajaran estafet learning. Hal ini dikarenakan metode pembelajaran ini berisi langkah-langkah jawaban mahasiswa secara berantai dan bergantian sampai mendapatkan jawaban 
akhir yang maksimal, sehingga kemampuan berpikir kritis mahasiswa dapat tumbuh dan hasil pembelajaran pada matakuliah metode numerik dapat meningkat.

Berdasarkan latar belakang tersebut, penulis tertarik untuk menganalisis lebih dalam mengenai penerapan metode pembelajaran estafet learning dan pengaruhnya terhadap peningkatan kemampuan berpikir kritis dan hasil belajar mahasiswa, mengkaji hubungan kemampuan berpikir kritis terhadap hasil belajar, dan mengkaji respon mahasiswa terhadap penerapan metode pembelajaran estafet learning.

\section{LANDASAN/KAJIAN TEORI \\ Metode Pembelajaran Estafet Learning}

Metode estafet learning merupakan metode adopsi dari matakuliah bahasa. Metode asli pada matakuliah bahasa adalah estafet writing. Estafet writing atau menulis berantai adalah metode learning by doing atau pembelajaran aktif yang melibatkan peserta didik secara aktif menulis karangan narasi dengan cara bersama-sama dan berantai (Cahyono, 2011). Dengan pengertian tersebut dapat simpulkan bahwa metode estafet learning adalah metode pembelajaran dengan memfokuskan kegiatan mahasiswa dalam menjawab soal dan permasalahan secara bergantian melaui target tertentu hingga mencapai kebenaran yang diharapkan.

$$
\text { Menurut Syathariah }
$$

langkah-langkah metode pembelajaran adalah Sebelum memulai metode estafet writing, guru menjelaskan sebuah tema dan materi yang akan diajarkan. (1) Guru menginstruksikan peserta didik membuat kelompok yang berjumlah 5-6 orang. (2) Setelah itu guru meminta peserta didik membuat satu kalimat pembuka. (3) Setelah peserta didik menulis kalimat pembuka, peserta didik itu menjadi orang pertama. Kemudian pada hitungan pertama, guru memberikan perintah untuk mengangkat tinggi buku milik peserta didik masingmasing, pada hitungan kedua guru menyuruh peserta didik menyerahkan buku miliknya ke teman sebelah kanannya. (4) Peserta didik tersebut menjadi orang ke dua yang harus melanjutkan karangan temannya dengan menambahkan satu kalimat lanjutan. Peserta didik wajib melihat kalimat sebelumnya untuk melanjutkan karangan berikutnya. (5) Setelah orang kedua selesai, guru kembali melakukan hitungan untuk diserahkan kepada teman sebelah kanannya, begitu seterusnya berputar searah jarum jam, hingga waktu yang ditentukan oleh guru. (6) Setelah waktu yang ditentukan guru selesai, buku latihan harus dikembalikan kepada pemilik awalnya. Pemilik buku membaca hasil karangan yang ditulis secara berantai dan menandai kalimat-kalimat yang tidak nyambung. (7) Guru menyuruh salah satu peserta didik menuliskan hasil menulis berantai dipapan tulis, (8) lalu guru dan peserta didik mengoreksi secara bersama.

Langkah-langkah di atas kemudian diadopsi berdasarkan kajian matakuliah metode numerik yaitu:

1) Dosen meminta mahasiswa untuk membuat kelompok.

2) Dosen memberikan soal metode numerik kepada salah satu ketua kelompok untuk dikerjakan.

3) Setelah mahasiswa tersebut mengerjakan satu tahap jawaban, kemudian dilanjutkan ke temennya untuk diteruskan.

4) Mahasiswa tersebut menjadi orang ke dua yang harus melanjutkan jawaban. 
5) Setelah orang kedua selesai, dosen kembali melakukan hitungan untuk diserahkan kepada teman sebelah kanannya, begitu seterusnya berputar searah jarum jam, hingga waktu yang ditentukan oleh dosen.

6) Setelah waktu yang ditentukan dosen selesai, lembar jawaban harus dikembalikan kepada pengisi awalnya (ketua kelompok). ketua kelompok mengevaluasi jawaban yang ditulis secara berantai.

7) Dosen menyuruh salah satu peserta didik untuk menuliskan hasil jawaban berantai dipapan tulis,

8) Kemudian dosen dan mahasiswa mengoreksi secara bersama.

\section{Kemampuan Berpikir Kritis}

Menurut Peter (2012), kemampuan berpikir kritis itu penting karena individu yang dapat berpikir kritis dapat pula untuk memecahkan masalah karena sebelum melakukan aksi, individu akan mempertimbangkan terlebih dahulu kemungkinan yang terjadi sesuai dengan penalaran yang dimiliki. Ennis (1993) mendefinisikan bahwa, berpikir kritis merupakan penalaran berpikir reflektif dalam menentukan apa yang harus dilakukan. Sejalan dengan itu Maričića dan Spijunovicb (2014) menberpikir kritis merupakan aktifitas intelektual kompleks yang menekankan pada beberapa kemampuan yaitu: 1). kemampuan merumuskan permasalahan, 2). Evaluasi, $3)$. Kepekaan terhadap masalah.

Menurut Abdullah (2013), Berpikir kritis merupakan suatu proses yang bertujuan untuk membuat keputusan yang masuk akal, sehingga apa yang kita anggap hal tersebut merupakan suatu kebenaran dapat dilakukan dengan benar.. Menurut Johnson (2010), berpikir kritis adalah sebuah proses terorganisir dan jelas yang digunakan melalui aktivitas mental seperti pemecahan masalah, pembuat keputusan, dan menganalisis asumsi-asumsi, serta penemuan secara ilmiah. Menurut Kurfiss (1988), berpikir kritis adalah suatu pengkajian yang bertujuan mengkaji situasi, fenomena, pertanyaan, maupun masalah untuk mendapatkan sebuah hipotesis atau kesimpulan dengan mengintegrasikan semua informasi yang tersedia sehingga dapat dijustifikasi secara yakin.

Berdasarkan pendapat beberapa ahli di atas, maka daat disimpulkan bahwa berpikir kritismerupakan kegiatan, keaktivan, kegigihan dan pertimbangan yang cermat tentang suatu keyakinan atau bentuk pengetahuan yang dapat diterima dan dipandang dari berbagai sudut alasan yang mendukung.

Menurut Ennis (1993) indikator kemampuan berpikir kritis dapat dikelompkkan menjadi 5 kelompok, yaitu sebagai berikut:

a. Klarifikasi dasar (Elementary Clarification): terbagi menjadi tiga indikator yaitu (1) melakukan identifikasi atau membuat rumusan pertanyaan, (2) melakukan analisis argumen, dan (3) bertanya dan menjawab pertanyaan klarifikasi dan pertanyaan yang menantang.

b. Memberikan alasan atas suatu keputusan (The Basis for The Decision); yaitu (1) memberikan pertimbangan kredibilitas suatu sumber dan (2) melakukan observasi dan memberikan pertimbangan hasil observasi.

c. Menyimpulkan (Inference); membuat deduksi dan memberikan pertimbangan hasil deduksi, 
membuat induksi dan memberikan pertimbangan hasil induksi, dan (3) membuat dan memberikan pertimbangan nilai keputusan.

d. Klarifikasi Lebih Lanjut (Advanced Clarification):; (1) melakukan identifikasi istilah dan memberikan pertimbangan definisi dan memberikan acuan pada asumsi yang tidak dinyatakan.

e. Dugaan dan Keterpaduan (Supposition and Integration); (1) memberikan pertimbangan dan memikirkan secara logis premis, alasan, asumsi, posisi, dan usulan lain yang tidak disetujui atau yang membuat merasa ragu-ragu tanpa membuat ketidaksepakatan atau keraguan tersebut mengganggu pikiran, dan (2) menggabungkan berbagai kemampuan lain dan berbagai disposisi dalam membuat dan mempertahankan jawaban.

\section{Hasil Belajar}

Hasil belajar sebagai tolak ukur yang digunakan guna menentukan tingkat keberhasilan pengetahuan dan pemahaman siswa terhadap suatu mata pelajaran. Hasil belajar dapat dinyatakan dengan nilai yang berupa huruf ataupun angka. Hasil belajar bisa berupa keterampilan, nilai dan sikap siswa. Melalui proses pembelajaran diharapkan siswa memperoleh kecakapan tertentu serta perubahan pada dirinya.

Menurut Sudjana (2001), hasil belajar adalah berbagai kemampuan yang dimiliki siswa setelah menerima pengalaman belajar. Hasil belajar dapat muncul melalui berbagai jenis perubahan atau pembuktian perilaku seseorang.

Hasil belajar merupakan suatu hal didapat seseorang setelah melakukan aktivitas belajar. Hasil belajar terlihat dari perubahan tingkah laku, yang bisa diamati dan diukur dalam bentuk perubahan pengetahuan (Knowledge), sikap (afektif) dan keterampilan (psikomotor). Hamalik (2002) menyatakan bahwa perubahan dalam belajar diartikan adanya peningkatan dan pengembangan ke arah yang lebih baik dibandingkan dengan sebelumnya.

Hasil belajar diperoleh melalui proses evaluasi, Mulyasa (2007) menyatakan bahwa evaluasi hasil belajar merupakan suatu aktivitas pengukuran perubahan perilaku. Hasil belajar ditunjukan melalui prestasi belajar yang merupakan indikator adanya perubahan tingkah laku siswa.

Dari proses pembelajaran diharapkan siswa memperoleh prestasi belajar yang baik sesuai dengan tujuan pembelajaran yang ditetapkan. Salah satu cara yang bisa dilakukan untuk mengetahui tingkat keberhasilan pembelajaran adalah menggunakan tes. Tes digunakan untuk menilai hasil belajar pada materi pelajaran yang diberikan guru. Sehingga, dapat disimpulkan bahwa hasil belajar merupakan tolak ukur yang menentukan tingkat keberhasilan siswa pada suatu materi pelajaran dari proses pembelajaran yang diukur melalui tes.

Menurut Syah (2006) secara umum faktor yang berpengaruh terhadap hasil belajar dapat dibedakan menjadi tiga, yaitu, 1) Faktor internal, meliputi keadaan/kondisi jasmani dan rohani siswa; 2) Faktor eksternal, yaitu kondisi lingkungan di sekitar siswa; 3) Faktor pendekatan belajar, yaitu jenis upaya belajar siswa yang dapat berupa strategi dan metode yang digunakan dalam pembelajaran. Sehingga, diharapkan melalui metode estafet learning hasil belajar siswa dapat meningkat lebih baik. 


\section{METODE PENELITIAN}

\section{Jenis Penelitian}

Jenis penelitian ini memuat penelitian kuantitatif dengan desain penelitian menggunakan model One sample Design yaitu dengan mengukur hasil fretest dan postest dan dilakukan interpretasi berupa uji gain, regresi dan korelasi.

\section{Waktu dan Tempat Penelitian}

Penelitian dilaksanakan pada Semester genap tahun ajaran 2018/2019. Tempat penelitian di Program Studi Teknik Informatika Fakultas Ilmu Komputer Universitas Kuningan.

\section{Subjek Penelitian}

Populasi penelitian adalah mahasiswa Angkatan 2017 semester 4 Program Studi Teknik Informatika Fakultas Ilmu Komputer Universitas Kuningan. Teknik Pengambilan sampel dilakukan dengan purposive sampling. Sampel yang diambil di kelas TINFC 2017 A sebanyak 34 orang.

\section{Prosedur}

Untuk memudahkan proses penelitian maka disusun prosedur sebagai berikut.

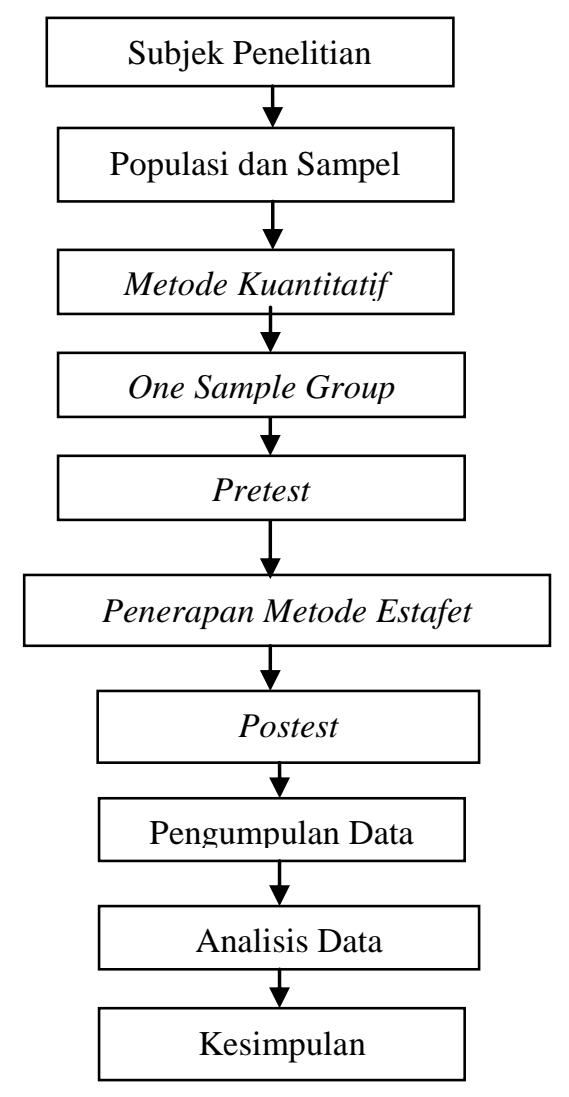

Gambar 1. Prosedur Penelitian

Data, Intrumen, dan Teknik instrumen yang digunakan disesuaikan

\section{Pengumpulan Data}

Instrumen penelitian merupakan alat yang digunakan untuk memperoleh atau mengumpulkan data-data selama kegiatan penelitian dilakukan. Jenis/bentuk dengan tujuan penelitian. Jenis instrumennya adalah:

1. Lembar Soal

Soal yang disusun berisi soal satu jenis soal untuk pretest dan postest 
berdasarkan materi yang telah ditentukan. soal fretest diberikan sebelum diterapkan metode pembelajaran estafet learning sedangkan soal postes diberikan setelah diterapkan metode pembelajaran estafet learning.

2. Lembar Observasi

Observasi berisikan form isian tentang pengamatan terhadap mahasiswa tentang proses penerapan metode pembelajaran estapet learning dan kemampuan berpikir kritis.

3. Lembar Kuesioner Mahasiswa

Kuesioner Berisi respon mahasiswa terhadap penerapan metode pembelajaran estapet learning diuraikan dalam rentang respon kuesioner sebagai berikut : Sangat Setuju (SS), Setuju (S), Tidak Setuju (TS), dan Sangat Tidak Setuju (STS).

\section{Teknik Analisis Data}

Teknik analisis data dilakukan berdasarkan rumusan masalah analisis data penelitian sebagai berikut:

1. Untuk menganalisis penerapan metode pembelajaran estafet learning terhadap peningkatan kemampuan berpikir kritis mahasiswa dilakukan dengan uji gain.
2. Untuk menganalisis penerapan metode pembelajaran estafet learning terhadap peningkatan hasil belajar mahasiswa dilakukan dengan uji gain.

3. Untuk menganalisis hubungan antara kemampuan berpikir kreatif dan hasil belajar mahasiswa dilakukan dengan uji korelasi.

4. Untuk menganalisis tanggapan mahasiswa terhadap penerapan metode pembelajaran estafet learning dilakukan analisis dengan skala likert

\section{HASIL PENELITIAN DAN PEMBAHASAN}

Proses yang dilakukan diawalai pengumpulan data, kemudian data tersebut dianalisis berdasarkan urutan yang telah ditetapkan dalam rumusan masalah dengan hasil sebagai berikut.

Untuk menganalisis peningkatan kemampuan berpikir kritis dari Penerapan Metode Estafet Learning, maka digunakan uji gain dengan hasil sebagai berikut:

Tabel 1. Hasil Gain Peningkatan Kemampuan Berpikir Kritis Mahasiswa

\begin{tabular}{llll} 
Uji Statistik & Nilai Pretest & Nilai Posttest & Gain \\
\hline Rata-Rata & 57,66 & 74,05 & 0,34 \\
Standar Deviasi & 15,36 & 8,08 & 0,15 \\
Minimum & 35 & 58,1 & $-0,16$ \\
Maximum & 95 & 94,2 & 0,55 \\
\hline
\end{tabular}

Tabel 1. menunjukan rata-rata nilai fretes dan postes mengalami peningkatan dari 57,66 menjadi 74,05 dengan nilai gain 0,34 sehingga dapat diartikan bahwa peningkatan berpikir kritis dalam kategori sedang. Hal ini dikarenakan metode estafet learning ini berisi langkah-langkah jawaban mahasiswa secara berantai dan bergantian sampai mendapatkan jawaban akhir yang maksimal, sehingga kemampuan berpikir kritis mahasiswa dapat tumbuh pada matakuliah metode numerik dapat 
meningkat. Hal ini sejalan dengan Pujiasih (2018) yang menyatakan pada saat pembelajaran matematika peseta didik perlu diarahkan pada kegiatan-kegiatan yang mendorong untuk belajar secara aktif, baik secara mental, fisik maupun sosial merupakan suatu upaya yang perlu dilakukan dengan berpikir kritis matematis.

Selanjutnya, untuk menganalisis peningkatan hasil belajar dari Penerapan Metode Estafet Learning, maka digunakan uji gain dengan hasil sebagai berikut.

Tabel 2. Hasil Gain Peningkatan Hasil Belajar Mahasiswa

\section{Uji Statistik}

\begin{tabular}{llll}
\hline Rata-Rata & 63,23 & 81,17 & 0,44 \\
Standar Deviasi & 14,36 & 10,52 & 0,29 \\
Minimum & 45 & 50 & $-0,5$ \\
Maximum & 90 & 95 & 0,80 \\
\hline
\end{tabular}

Dari Tabel 2. menunjukan rata-rata nilai pretes dan postes mengalami peningkatan dari 63,23 menjadi 81,17 dengan nilai gain 0,44 sehingga dapat diartikan bahwa peningkatan hasil belajar dalam kategori sedang. Hal tersebut menunjukkan bahwa estafet learning memberikan kontribusi terhadap peningkatan hasil belajar mahasiswa. Seperti pendapat Syah (2006) salah satu yang mempengaruhi hasi belajar peserta didik adalah faktor pendekatan belajar yang dapat berupa strategi dan metode yang digunakan melakukan kegiatan pembelajaran.

Analisis dalam menentukan hubungan kemampuan berpikir kritis dan hasil belajar yaitu dengan uji korelasi dengan bantuan software SPSS. Hasil uji korelasi ditampilkan pada tabel berikut.

Tabel 3. Hubungan Berpikir Kritis dan Hasil Belajar Mahasiswa

\begin{tabular}{llll}
\hline & & Berpikir_Kritis & Hasil_Belajar \\
\hline \multirow{3}{*}{ Berpikir_Kritis } & Pearson Correlation & 1 &, $607^{* *}$ \\
& Sig. (2-tailed) & &, 000 \\
& N & 35 & 35 \\
Hasil_Belajar & Pearson Correlation &, $607^{* *}$ & 1 \\
& Sig. (2-tailed) &, 000 & \\
& N & 35 & 35 \\
\hline
\end{tabular}

Tabel 3. menunjukan nilai korelasi $\mathrm{r}$ $=0,607$ artinya $>0,5$ maka dapat disimpulkan hubungan kemampuan berpikir kritis dengan hasil belajar memiliki hubungan yang cukup kuat. Artinya siswa yang memiliki kemampuan berpikir kritis yang baik akan memperoleh hasil belajar yang baik juga. Hal tersebut sesuai dengan pendapat Chukwuyenum, (2013), Jacob,
(2012), NCTM, (2000), Hendryawan, dkk., (2017) yang meyatakan bahwa pengembangan kemampuan berpikir kritis dapat meningkatkan prestasi matematika.

Hasil kuesioner berupa tanggapan mahasiswa terhadap penerapan metode estafet learning dipaparkan pada Tabel dan Grafik sebagai berikut. 
Tabel 4. Hasil Respon mahasiswa terhadap penerapan metode pembelajaran estafet learning

\begin{tabular}{|c|c|c|c|c|c|c|c|c|c|c|}
\hline \multirow{2}{*}{ Respon } & \multicolumn{10}{|c|}{ Butir Pernyataan } \\
\hline & 1 & 2 & 3 & 4 & 5 & 6 & 7 & 8 & 9 & 10 \\
\hline STS & 0 & 0 & 0 & 0 & 0 & 0 & 0 & 0 & 0 & 0 \\
\hline $\mathrm{TS}$ & 4 & 10 & 7 & 6 & 6 & 4 & 4 & 14 & 4 & 2 \\
\hline$S$ & 19 & 8 & 15 & 13 & 12 & 18 & 16 & 7 & 14 & 23 \\
\hline SS & 12 & 17 & 13 & 16 & 17 & 13 & 15 & 14 & 17 & 10 \\
\hline Total & 35 & 35 & 35 & 35 & 35 & 35 & 35 & 35 & 35 & 35 \\
\hline STS & \multicolumn{10}{|c|}{0,00} \\
\hline TS & \multicolumn{10}{|c|}{17,43} \\
\hline $\mathrm{S}$ & \multicolumn{10}{|c|}{41,43} \\
\hline SS & \multicolumn{10}{|c|}{41,14} \\
\hline Total \% & \multicolumn{10}{|c|}{100,00} \\
\hline
\end{tabular}

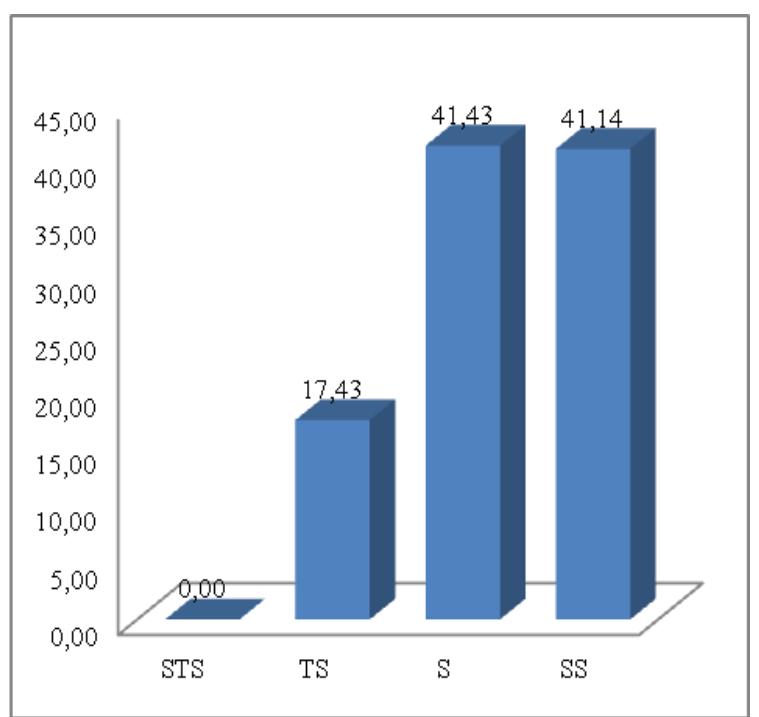

Gambar 2. Persentasetanggapan mahasiswa terhadap penerapan metode pembelajaran estafet learning

Dari Tabel dan grafik di atas, menunjukan bahwa respon mahasiswa terhadap mayoritas pada kisaran setuju dan sangat setuju dengan persentase masingmasing sebesar $41,43 \%$ dan $41,14 \%$. Hal ini dapat disimpulkan bahwa respon mahasiswa > $80 \%$ artinya responnya bernilai positif. Hal tersebut berarti mahasiswa menyukai belajar dengan menggunakan estafet learning. Respon yang positif akan berdampak baik terhadap hasil belajar mahasiswa. karena ketika mahasiswa menyenangi suatu aktivitas dalam proses pembelajaran akan berdampak pada motivasi mahasiswa dalam belajar. Hal ini sejalan dengan Brown et all, (2007) aktivitas pemecahan masalah pada saat proses pembelaajran adalah salah satu hal yang berhubungan dengan kesenangan terhadap matematika.

\section{SIMPULAN DAN SARAN \\ Simpulan}

Berdasar pada hasil analisis data dan pembahasan yang telah dipaparkan, maka dapat disimpulkan sebagai berikut. 
1. Adanya peningkatan kemampuan berpikir kritis mahasiswa dari penerapan metode estafet learning.

2. Adanya peningkatan hasil belajar mahasiswa dari penerapan metode estafet learning.

3. Adanya hubungan kemampuan berpikir kreatif dengan hasil belajar mahasiswa dari penerapan metode estafet learning .

4. Adanya tanggapan yang positif dari mahasiswa terhadap penerapan metode estafet learning .

\section{Saran}

Hasil penelitian diperoleh bahwa adanya peningkatan kemampuan berpikir kritis dan hasil belajar mahasiswa dalam mata kuliah metode numerik setelah menggunakan metode estafet learning, akan tetapi penigkatan masih dalam kategori sedang. Berdasarkan hasil tersebut estafet learning dapat dijadikan salah satu metode pembelajaran pada mata kuliah metode numerik. Agar hasil peningkatan kemampuan berpikir kritis dan hasil belajar lebih tinggi, peneliti selanjutnya dapat mengkominasikan metode estafet learning dengan pendekatan maupun model pembelajaran yang sesuai dengan karakteristik mahasiswa.

$$
\text { Pada dasarnya mahasiswa }
$$

memberikan respon yang positif atau dengan kata lain mahasiswa senang belajar dengan menggunakan metode estafet learning. Sehingga, dosen dapat menggunakan metode estafet learning untuk pembelajaran mata kuliah yang lainnya. Hal yang paling penting juga, dalam proses pembelajran pada setiap mata kuliah hendaknya memacu mahasiswa untuk mengasah kemampuan berpikir kritis, karena terdapat korelasi yang kuat antara kemampuan berpikir kritis dan hasil belajar mahasiswa.

\section{DAFTAR PUSTAKA}

Abdullah, I., H. (2013). Berpikir kritis matematik. Delta-pi: Jurnal Matematika dan Pendidikan Matematika, 2(1), 66 - 75.

Brown, M. et all. (2007). "I Would Rather Die": Attitudes of 16 year olds Towards Their Future Participation in Mathematics. Proceedings of The British Society for Research into Learning Mathematics.

Chukwuyenum, A. N. (2013). Impact of critical thinking on performance in mathematics among senior secondary school students in Lagos state. IOSR Journal of Research \& Method in Education, 3(5), 18 - 25.

Ennis, R. H. (1993). Critical Thinking Assessment. Theory Into Practice, 32(3), pp. 179-186.

Hamalik, O. (2002). Proses Belajar Mengajar. Jakarta: Bumi Asara.

Hendryawan, S., Yusuf, Y., Siregar, I., Wachyar,, T., Y., Dwiyanti, W. (2017). Analisis kemampuan berpikir kritis matematis siswa SMP tingkat rendah pada pembelajaran berbasis masalah dengan green's motivational strategies. Aksioma, 8(2), $50-58$.

Jacob, S. M. (2012). Mathematical achievment and critical thinking skills in asynchronous discussion forums. Procedia-social and Behavioral Sciences, 31, pp. 800-804.

Johnson, E., B. (2010). Contextual Teaching and Learning: Menjadikan Kegiatan Belajar Mengajar Mengasyikkan dan Bermakna. Bandung: Kaifa.

Kurfiss, J. G. (1988). Critical thinking: Theory, research, and possibilities. Washington: ASHE (Association for the Study of Higher Education).

Maricica, S., \& Špijunovicb, K. (2014). Developing Critical Thinking in Elementary Mathematics Education through a Suitable Selection of Content and Overall Student 
Performance. Procedia - Social and Behavioral Sciences, 180, 653 - 659.

Mulyasa, E. (2007). Implementasi Kurikulum 2004: Perpaduan Pembelajaran KBK. Bandung: Rosda

NCTM. (2000). Principles and standars for school mathematics. Roston, VA: National Council of Teacher of mathematics.

Peter, E. E. (2012). Critical Thinking: Essence for Teaching Mathematics and Mathematics Problem Solving Skills. African Journal of Mathematics and Computer Science Research, 5(3), 39-43. doi: 10.5897/ajmcsr11.161

Pujiasih, F. (2018). Profil kemampuan berpikir kritis matematis siswa dalam pemecahan masalah soal SPLDV ditinjau dari kemampuan matematika. Jurnal Karya Pendidikan Matematika, 5(2), pp. $9-10$.

Putri, F., M., Darmawijoyo, Susanti, E. (2018). Kemampuan berpikir kritis matematis siswa dalam pembelajaran matematika menggunakan teori APOS. Histogram: Jurnal Pendidikan Matematika, 2(1), pp. 1 11.

Sudjana, N. (2001). Penilaian Hasil Proses Belajar Mengajar. Bandung: Remaja Rosdakarya.

Syah, M. (2006). Psikologi Belajar. Jakarta: PT Raja Grafindo Persada.

Syathariah, S. (2011). Estafet Writing (Menulis Berantai) "Solusi dalam Menulis Cerpen bagi Siswa SMA/MA. Yogyakarta: Letikaprio. 